\title{
海洋深層水放水に関する基礎的実験 \\ FUNDAMENTAL EXPERIMENTAL STUDY ON DEEP SEAWATER OUTFALL
}

\author{
1正会員 工修 株式会社 東京久栄 （テ103-0027 東京都中央区日本橋3-1-15） \\ 2正会員 Ph. D 東海大学教授 海洋学部 海洋土木工学科（†424-8610 静岡県清水市折戸3-20-1） \\ 3正会員 工博 東海大学教授 海洋学部 海洋土木工学科（†424-8610 静岡県清水市折戸3-20-1）
}

\begin{abstract}
This paper shows Fundamental experimental study on Deep seawater outfall. The result showed that condition of plume mixing, Deep seawater outfall is related to internal-Froude-number (Fr).

Deep seawater has three characters. The characteristic of Deep seawater is higher purity, cold and nutrient-rich. Coastal environment is recovered isoyake by utilizing nutrient-rich or cold Deep seawater . A new technology essential for the control Deep seawater outfall.
\end{abstract}

Key Words : deep seawater, deep seawater outfa11, interna1-Froude-number (Fr), isoyake

\section{1.はじめに}

海洋資源として注目を浴びている海洋深層水は、 一般に表層水と比べ、富栄養、清浄、低水温、高密 度と違った特性をもっている。深層水の持つ高い生 物生産力を利用し、放水による海域環境の改善効果 つまり海域の肥沃化、磯焼けによって失われた藻場 の回復が考えられている。一方、表層水と違ら性質 を持つ深層水を海域に放流することによる泠水塊の 発生、栄養塩類投入による海域環境の悪化などの海 域へのインパクトが懸念される。

一般に深層水は水深約 $300 \mathrm{~m}$ で水温約 $10^{\circ} \mathrm{C}$ 、陸上 では約 $15 \sim 20^{\circ} \mathrm{C}$ と低温かつ高塩分であり、約 20 ～ $30^{\circ} \mathrm{C}$ と温か心表層水と比べて密度が大きく、負の浮 力（重力）の影響を受けて密度流として鉛直運動を 行うものと考えられる。

密度流に関する研究は、火力・原子力発電所から の温排水の拡散現象を解明し、影響範囲をシミュ レーションする必要性から研究されてきた。現在、 高知県で試験的に行われているような深層水放流に よる海域肥沃化や、磯焼け回復への利用を考えるの であれば、混合促進の観点だけでなく、放流した深 層水の混合特性を把握することによって、放流深層 水をいかにコントロールすることが可能であるか検 討することが大切である。

そこで、本論文は活用後の深層水を海域に表層水
平放流したときの拡散状況について、水温計測と可 視化手法を用いて実験的に求めた結果を基に考察し たものである。

\section{2. 実験装置・実験方法}

実験は図-1に示す実験装置を製作して行った。高 さ $53.5 \mathrm{~cm}$, 長さ $300 \mathrm{~cm}$, 幅 $30 \mathrm{~cm}$ の低水槽部に水深が $40 \mathrm{~cm}$ になるように温度調節を行った水を入れ、底面

\section{上方断面図}

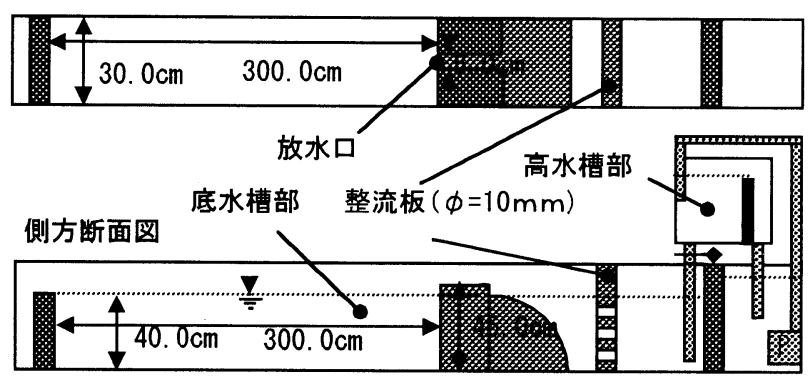

図-1 実験装置

より $40 \mathrm{~cm}$ の位置に設けてある幅 $5.0 \mathrm{~cm}$ の放出口から 温度調節した水を表層放流した。なお、流量は高水 槽のバルブで調節した。水温測定断面は、放出口を $X=0 \mathrm{~cm}$ として X=5, 10, 15, 20, 25, 30,40,50,60,70cm の 10断面とし、各断面で水深方向に測点を変化させて 水温を計測しに。水温測定は、熱伝対センサーく 
$2.3 \mathrm{~mm}$, 先端 $\phi 1.6 \mathrm{~mm}$ )をデータコレクタ (安立計器 (株)）に接続して記録した。なお、サンプリング時 間は1secである。放流平均流速 $\left(\mathrm{U}_{0}\right)$ は、測定した放 出口の水深(h) から求めた。

実験は、放流深層水と海域の温度差 $(\Delta \mathrm{T})$ と、放 流流速の相違を考慮して、6ケースについて行った。 これらの実験条件は $\Delta \mathrm{T}=5^{\circ} \mathrm{C}, 10^{\circ} \mathrm{C}$ で幅 $2 \mathrm{~m}$ の放出口 から日量 $1000 \mathrm{~m}^{3}, 2500 \mathrm{~m}^{3}, 5000 \mathrm{~m}^{3}$ の水を放流するの に相当する。また、各実験ケースは、（1）式で表さ

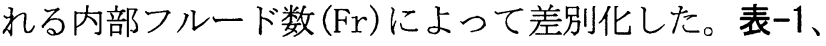
表-2に実験条件を示す。

可視化実験は放流水をウラニンで染色し、水路上 面からブラックライトを照射し、水路側面からビデ オカメラで撮影した。可視化実験はcase7, case8の2 ケース行った。

表-1 実験条件 (その1)

\begin{tabular}{|c|c|c|c|c|}
\hline case NO. & $Q\left(\mathrm{~cm}^{3} / \mathrm{s}\right)$ & $\mathrm{b}(\mathrm{cm})$ & $\mathrm{h}(\mathrm{cm})$ & $\mathrm{u}_{0}(\mathrm{~cm} / \mathrm{s})$ \\
\hline \hline case 1 & 4.14 & 5.00 & 0.48 & 1.73 \\
\hline case 2 & 15.05 & 5.00 & 0.56 & 5.38 \\
\hline case 3 & 34.19 & 5.00 & 0.60 & 11.40 \\
\hline case 4 & 3.72 & 5.00 & 0.48 & 1.55 \\
\hline case 5 & 11.3 & 5.00 & 0.50 & 4.52 \\
\hline case 6 & 34.17 & 5.00 & 0.60 & 11.39 \\
\hline case 7 & 13.62 & 5.00 & 0.55 & 4.95 \\
\hline case 8 & 7.78 & 5.00 & 0.50 & 3.11 \\
\hline
\end{tabular}

表-2 実験条件 (その2)

\begin{tabular}{|c|c|c|c|c|c|}
\hline case NO. & $\mathrm{T}_{1}\left({ }^{\circ} \mathrm{C}\right)$ & $\mathrm{T}_{2}\left({ }^{\circ} \mathrm{C}\right)$ & $\rho_{1}\left(\mathrm{~g} / \mathrm{cm}^{3}\right)$ & $\rho_{2}\left(\mathrm{~g} / \mathrm{cm}^{3}\right)$ & $\mathrm{Fr}$ \\
\hline \hline case 1 & 10.0 & 15.0 & 0.99970 & 0.99910 & 3.25 \\
\hline case 2 & 10.0 & 15.0 & 0.99970 & 0.99910 & 9.37 \\
\hline case 3 & 10.8 & 15.8 & 0.99962 & 0.99898 & 18.57 \\
\hline case 4 & 11.3 & 21.1 & 0.99957 & 0.99798 & 1.79 \\
\hline case 5 & 11.0 & 21.3 & 0.99960 & 0.99793 & 5.00 \\
\hline case 6 & 11.0 & 21.3 & 0.99960 & 0.99793 & 11.49 \\
\hline case 7 & 11.1 & 16.3 & 0.99959 & 0.99890 & 8.12 \\
\hline case 8 & 11.1 & 21.2 & 0.99959 & 0.99795 & 3.47 \\
\hline
\end{tabular}

ここで、

$\mathrm{Q}:$ 放流流量 $\left(\mathrm{cm}^{3} / \mathrm{s}\right)$
$\mathrm{b}:$ 放流口幅 $(\mathrm{cm})$
$\mathrm{h}:$ 放流口水深 $(\mathrm{cm})$
$\mathrm{U}_{0}:$ 放流平均流速 $(\mathrm{m} / \mathrm{s})$
$\mathrm{T}_{1}$ :放流水の水温 $\left({ }^{\circ} \mathrm{C}\right)$
$\mathrm{T}_{2}$ : 周囲水の水温 $\left({ }^{\circ} \mathrm{C}\right)$
$\rho_{1}:$ 放流水の密度 $\left(\mathrm{g} / \mathrm{cm}^{3}\right)$
$\rho_{2}:$ 周囲水の密度 $\left(\mathrm{g} / \mathrm{cm}^{3}\right)$
$\mathrm{Fr}:$ 内部フルード数

$$
F r=\frac{u_{0}}{\sqrt{\frac{\Delta \rho}{\rho_{1}} g h}}
$$
$\Delta \rho: \Delta \rho=\left|\rho_{1}-\rho_{2}\right| \quad\left(\mathrm{g} / \mathrm{cm}^{3}\right)$
$\mathrm{g}:$ 重力加速度 $\left(\mathrm{m} / \mathrm{s}^{2}\right)$
$\mathrm{h}$ : 放流口での水深 $(\mathrm{cm})$

\section{3. 水温計測結果及び考察}

水温計測結果を図-2、図-3に等温度分布図で示す。 図-2は $\Delta \mathrm{T}=5^{\circ} \mathrm{C}$ と一定にし、放流平均流速を変化さ せたcase1, case2, case3の等温度分布である。また、 図一3は $\Delta \mathrm{T}$ 約 $10^{\circ} \mathrm{C}$ とし、放流平均流速を変化させ たcase4, case5, case6の等温度分布である。

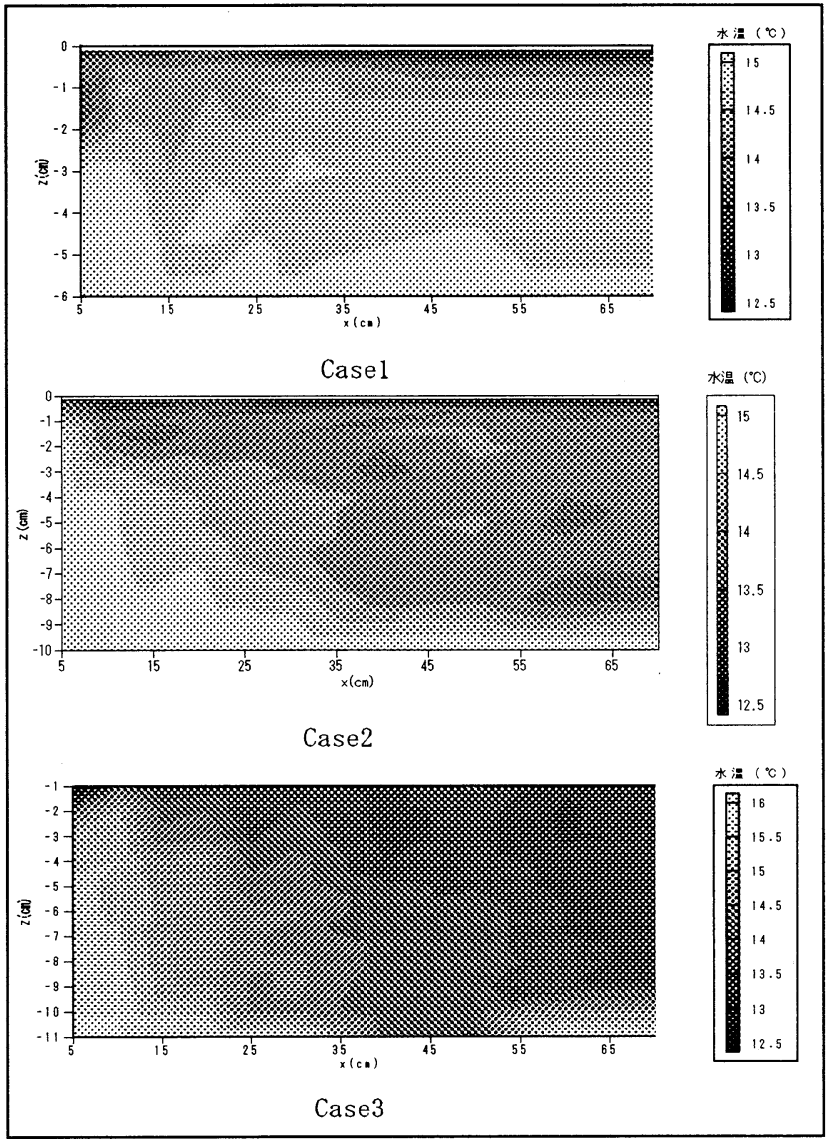

図-2 等温度分布 (case1, case2, case3）

図-2で示している case $1,2,3$ は、 $\Delta \mathrm{T}=5{ }^{\circ} \mathrm{C}$ ある ため、密度差は小さいがcase1からcase3になるに従 い诣が大きくなるため、表-2に示すように内部フ ルード数が順に大きくなる。よって、case 1,2,3の 順に浮力効果が減少することから内部フルード数が 大きくなる。放流水は流下寸るにつれ下方に拡散す る。また、内部フルード数が大きくなるに従い流下 方向へ広がり幅を増しながら拡散していることがわ かる。

図-3で示しているcase4, 5, 6も、図-2と同様に拡 散状況は内部フルード数に関係していると考えられ 内部フルード数が大きくなるに従い下方に拡散する。 また、内部フルード数が小さいもののほうが放水口 付近に滞留していることが確認できる。 ここで、 


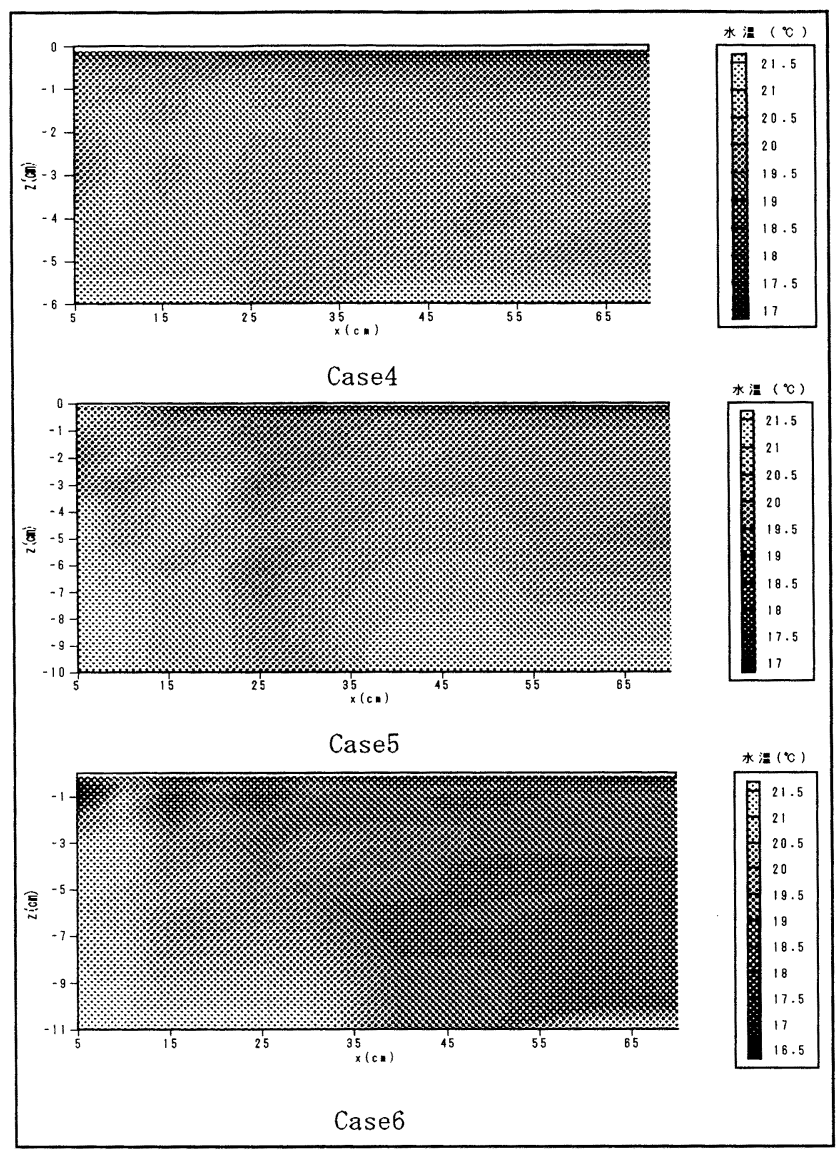

図-3＼cjkstart等温度分布（case4, case5, case6）

\section{4. 可視化実験結果及び考察}

写真-1、写真-2、はそれぞれcase7, case8の経過 時間ごとの流況である。放流直後に表層を流下した 放流水は、斜めに落下しながら広がり、その後、底 面に到達した放流水は底面上を拡がっていく。また、 底面上の放流水のフロントは徐々に流下するが、底 面に沿って放流口の方人向から流れもある。境界面 における混合は、放流水の界面に発生した渦の闖入 による渦拡散によることがわかる。

\section{5. 結論}

以上のことより、結論として次のことがいえる。

1. 放流水の拡散状況は、内部フル・ド数に関係し、 その現象は内部フルード数で整理できる。

2. 表層水平放流を行ったとき、内部フルード数が 小さいときほど放流口に近い位置で放流水が沈 降する傾向が有る。

3. 放流水の拡がりは、放流水の界面に発生した渦 の闖入による渦拡散によるものである。

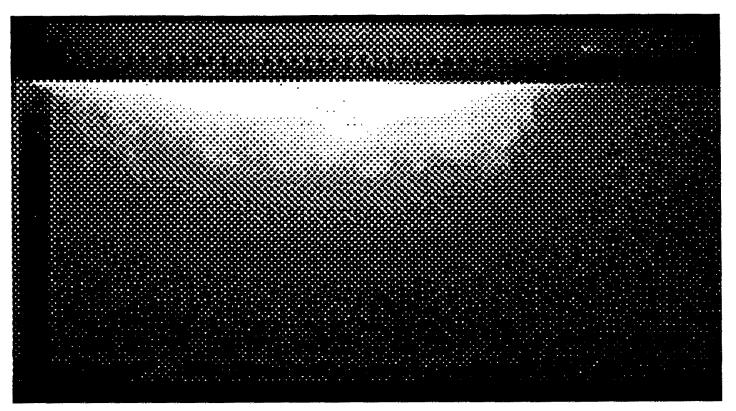

(a) 40 秒後

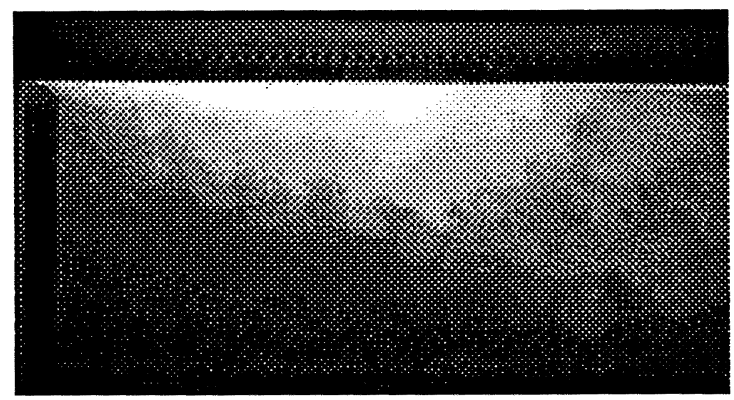

（b）80秒後

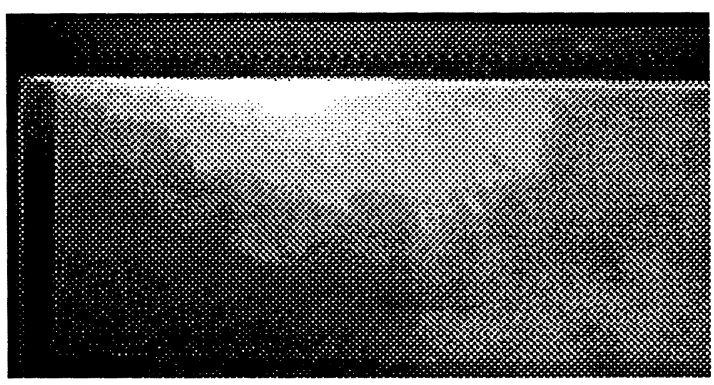

(c) 120 秒後

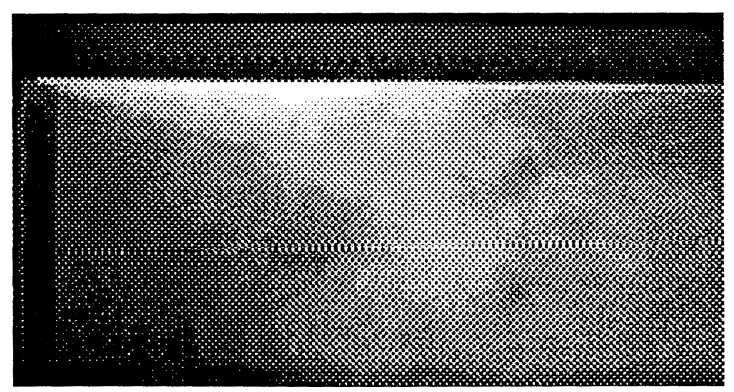

（d） 160 秒後

写真-1 流況の時間変化 (case7) 


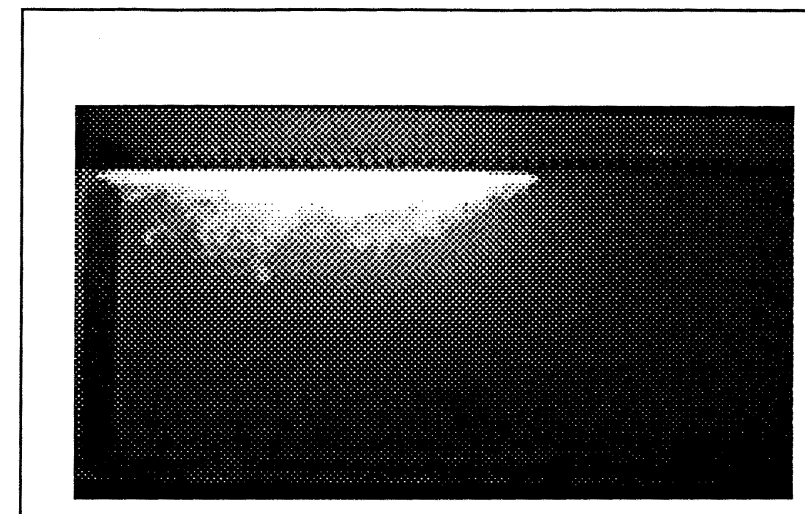

（a） 20 秒後

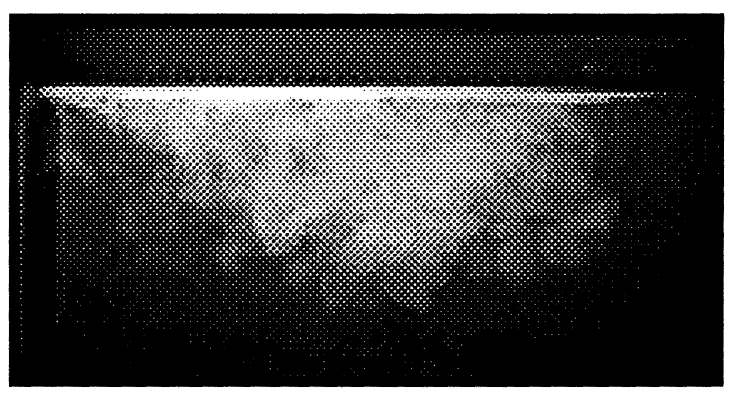

(b) 60 秒後

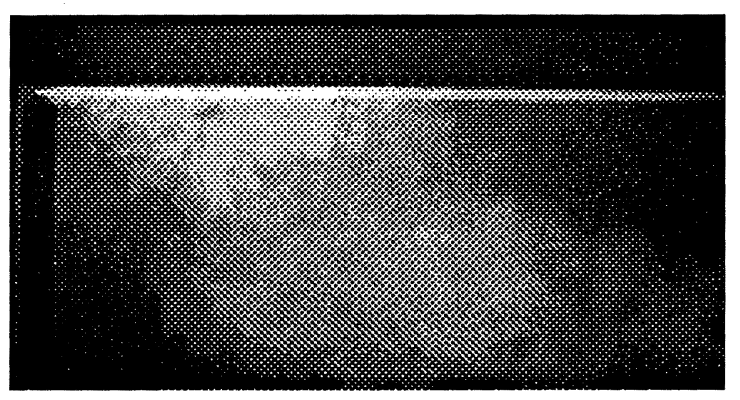

(c) 100秒後

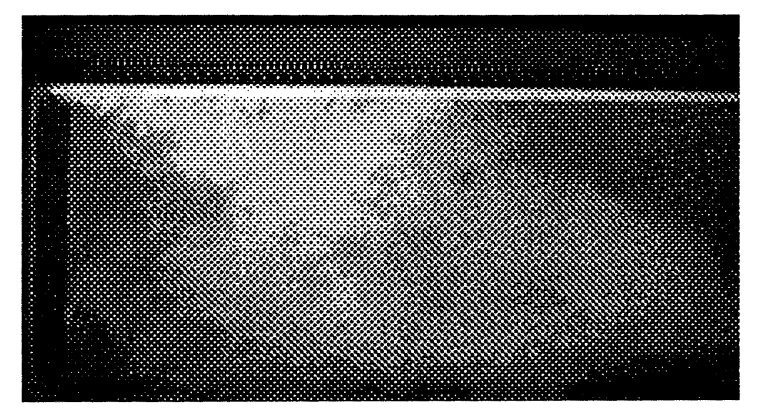

(d) 140 秒後

\section{6. おわりに}

先に述べたように、密度流に関する研究は、火 力・原子力発電所からの温排水の拡散現象を解明し、 影響範囲をシミュレーションする必要性から研究さ れてきた。しかし、放流した深層水を海域の環境改 善のために利用するためには、混合促進の観点だけ でなく利用するのに最適な放流を創造する必要があ る。そのためにも、今後、放流水深、放流水の水温、 などの、放流条件を変化させた実験を行い、放流深 層水を利用するためのガイドラインを作成すること が望まれる。

\section{参考文献}

1）山内一彦：海洋深層水取放水計画の基礎的研究，1999 年度東海大学大学院修士論文, 1999 .

2) 小松雅之ほか: 海洋深層水放流による海域肥沃化検討 のためのモデル開発, 第 3 回海洋深層水利用研究会全 国集会講演要旨集, pp. 11-12, 1998.

写真-2 流況の時間変化（case8） 